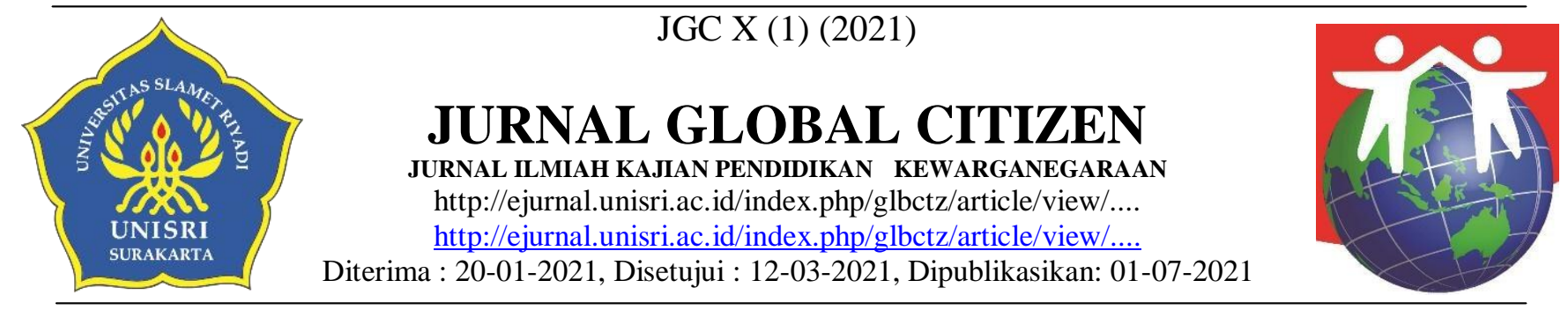

\title{
WABAH COVID-19 YANG BERDAMPAK PADA HAM DI DUNIA
}

\author{
Febri Widya Puspitasari ${ }^{(1)}$, Anita Trisiana ${ }^{(2)}$,Fadilla Budiardhani ${ }^{(3)}$ \\ Universitas Slamet Riyadi Surakarta
}

\begin{abstract}
ABSTRAK
Covid-19 berasal dari China lebih tepatnya di kota Wuhan.Covid-19 sekarang sudah semakin meluas.Bukan hanya itu,covid-19 juga sudah menjadi status darurat international.Covid-19 juga sudah ditetapkan oleh WHO.Nicholas Bequelin menyatakan wabah virus berpotensi mempengaruhi HAM di dunia,terpenting dalam kesehatan.Di suatu negara harus ada fasilitas untuk layanan kesehatan.Bahkan tidak hanya mengancam kesehatan tetapi juga mengancam perekonomian,pendidikan,sosial dan lainnya.Hal itu membutuhkan gotong royong masyarakat untuk melawannya agar tercapai tujuan kehidupan yakni aman dan sejahtera.Ancaman wabah covid-19 ini juga dapay membuat semua warga negara di dunia ini tidak mendapat kebebasan. Selain dalam segi kebebasan juga dalam segi mendapat informasi.Dalam pandemic ini sangat susah mengakses informasi karena dijaga sangat ketat privasi informasi tersebut.Hak asasi manusia semuanya sudah dijamin bukan hanya di Indonesia saja tetapi seluruh dunia sangat berpengaruh dalam Hak Asasi Manusia.Disaat seperti ini maka kita sebagai warga negara harus memiliki solidaritas yang tinggi untuk membantu pemerintah dalam usahanya untuk memusnahkan virus,seperti mematuhi peraturan yang telah ditetapkan pemerintah.Tidak hanya warga masyarakat namun juga berbagai perusahaan ataupun lembaga yang juga harus ikut melakukan langkah-langkah memusnahkan covid seperti halnya 3M,bahkan harus menghentikan kegiatannya.Setelah seluruh masyarakat di dunia mematuhi peraturannya pemerintah dan berusaha membiasakannya dalam kehidupan sehari-hari buktinya terdapat penurunan pasien yang terinfeksi virus.Bahkan sudah tidak banyak lagi kekerasan yang terjadi di masyarakat dan di lingkungan keluarga.
\end{abstract}

\section{Kata Kunci : Covid-19, Hak Asasi Manusia,Warga Negara}




\begin{abstract}
Covid-19 originated in China,more precisely in the city of Wuhan.Covid-19 has now become more widespread.Not only that,covid-19 has also become an international emergency status.Covid-19 has also been determined by WHO.Nicholas Bequelin stated that the virus outbreak has the potential to affect human rights in the world,most importantly in health,In a country there must be facilities for health services.In fact,it does not only threaten health but also threarens the economy, education, social and others, which requires community cooperation to fight it to achieve the goal of life, namely safety and prosperity.The threat of this corona epidemic can also make all citizens of the country in this world not get freedom.Apart from the aspect of freedom it is also in terms of obtaining information.In this pandemic.it is very difficult to access information because the privacy of the information is strictly guarded.All human rights are guaranteed.Not only in Indonesia but all over the world are very influential in human rights.At times like this, we as citizens must have high solidarity to help the government in its efforts to eliminate the virus,such as complying with regulations set by the government.Not only community members but also various companies or institutions that must also take steps to destroy Covid like 3M,even have to stop its activities.After all people in the world comply with government regulations and try to get used to it in their daily lives, the proof is that there is a decrease in patients infected with the virus.In fact,there is not much violence that occurs in the community and in the family environment.
\end{abstract}

Keywords: Covid-19, Human Rights, Citizen 


\section{PENDAHULUAN}

Saat ini marak-maraknya muncul berita berupa virus yang berbahaya bernama covid 19(corona).Hewan pun juga berbahaya karena dapat menulari ke manusia melewati air liur. Virus ini bukan di indonesia saja tetapi diseluruh dunia sangat marak dengan virus corona. Kasus pertama ditemukan di Wuhan, Republik Rakyat Tionghoa. Virus corona ini telah menjadi salah satu wabah yang tersebar di berbagai negara. Covid 19 ini menjadi salah satu ketakutan terbesar bagi manusia.Semenjak saat itu, masyarakat lebih berhati-hati dalam beraktivitas. Virus corona juga menjadi perhatian masyarakat dunia.

Penyakit menular adalah hasil perpaduan berbagai faktor yang saling mempengaruhi.Banyak faktor yang yang mempengaruhi salah satunya factor lingkungan.Di kota Wuhan menjadi pusat virus korona banyak menelan korban jiwa bukan hanya itu saja tetapi di seluruh dunia juga banyak menelan korban jiwa.

Covid-19 sangat berpengaruh dalam hak asasi manusia bukan hanya di Indonesia saja tetapi juga di seluruh dunia.Covid-19 bukan main-main juga sekarang sudah jadi pandemi.Pandemi juga sangat berpengaruh dalam segala bidang contohnya bidang ekonomi,social,dan budaya.Selain itu juga sangat berpengaruh dalam hak asasi manusia dalam segi kesehatan dan kebebasan.Bukan hanya segi kesehatan,social,ekonomi tetapi juga dalam penyelenggaraan olahraga.

Dalam konferensi kesehatan pada hari jumat, zhong memperkirakan bahwa pandemi,yang telah membuat lebih dari 45 juta orang sakit diseluruh dunia itu, akan bertambah buruk pada saat musim dingin mendekat Zhong mengklaim"bahwa gelombang kedua akan meletus secara global dan terus melanda banyak negara". Peran masyarakat sangat penting dalam mencegah wabah virus corona ini. Pemerintah serta penduduk warga negara Indonesia maupun seluruh dunia harus bergotong royong mencegah virus korona ini.

\section{METODE}

Dalam riset ini menggunakan metode kualitatif yakni menganalisis dan deskriptif dengan proses dan makna lebih di utamakan. Yang bertujuan agar pembaca memahami peristiwa apa yang terjadi di alam serta memahami apa makna serta informasi hal-hal apa saja yang bisa mempengaruhi tindakan warga dalam menghindari covid-19 di dunia dan khususnya di Tanah air.

Penelitian contohnya mengenai perilaku,tindakan,peristiwa,permasalahan.

Riset ini menggunakan riset permasalahan yang artinya strategi dalam riset untuk mengubah permasalah khusus untuk menghimpun informasi ,dan mendapatkan uraian dari permasalahan itu. Mengetahui seberapa pahamnya warga negara atas penanggulangan penanganan covid-19 serta usaha pemerintah untuk menanganinya.

Peneliti menganalisa permasalahan covid-19 seperti gejala yang dialami, lalu mengumpulkan data dengan cara mengambil informasi dari berbagai sumber mengenai jumlah positif, meninggal bahkan yang sembuh serta informasi kehidupan sosial ekonomi yang juga terdampak.

Peneliti juga menguraikan arti dari kebebasan sebagai warga negara,kebebasan disini memiliki arti jika warga berhak melakukan aktifitasnya secara bebas bahkan mendapatkan haknya terhadap kesehatan,kebebasan bergerak, beraktivitas. Namun,adanya covid ini membuat warga negara sulit mendapatkan kebebasannya sebagai warga negara.

Pada riset ini juga membahas bagaimana kedudukan pemerintah dan warga negara dalam usahanya untuk menghindari covid-19 serta usaha apa saja yang dilakukan masyarakat agar tetap dirumah saja dan melakukan social distancing.

Sejak diumumkannya sebuah pandemi,telah menjadi tantangan global. Kemudian pada riset ini menjabarkan bagaimana tata cara pencegahan pada masyarakat. Selain pemerintah ,masyarakat juga harus bersama-sama agar covid-19 ini tidak tersebar luas.Dampak yang ditimbulkan dari covid-19 ini sangat besar bagi seluruh dunia.Semua elemen di masyarakat ini harus mempunyai semangat tinggi agar dampak yang ditimbulkan tidak semakin besar .Jika 
bersama-sama mencegah virus corona ini maka covid-19 ini dapat hilang .

Covid-19 sangat berdampak pada seluruh elemen.Khususnya dalam Hak Asasi Manusia . Dalam segi kesehatan juga sangat mengancam pada hak asasi manusia.Sangat susah memulihkan keadaan ini.Apalagi sekarang sudah menjadi pandemi.Para tenaga medis juga kekurangan alat pelindung diri itu contoh mengancam hak asasi manusia.

\section{HASIL DAN PEMBAHASAN}

\section{A.Covid-19 (Virus Corona)}

Coronavirus adalah penyakit yang menyerang imunitas tubuh seperti infeksi saluran pernapasan.Virus corona sudah sangat banyak yang terinfeksi .biasanya akan terkena 1 kali semasa hidupnya.Covid-19 juga bisa mengakibatkan penyakit yang berbahaya lainnya.Khususnya dalam pernapasan .Penyakit tersebut bisa berakibat fatal.Penyakit itu sangat mudah menular dengan melakukan kontak langsung sama orang yang terkena.Selain itu.ada juga penyakit yang ada nanahnya.penyakit tersebut bisa dengan mudah menginfeksi semua kalangan.

Dalam kelompok penyakit corona itu ada tujuh jenisnya salah satunya covid-19.Dan ada gangguan pernapasan Timur Tengah.Dan banyak lagi jenis virus corona.Semua penyakit tersebut sangat berbahaya bagi tubuh kita.Biasanya juga ditandai dengan flu biasa dan batuk.Dengan mudah juga penyakit diatas merenggut korban jiwa.

Semua orang bisa terkena Covid-19..Namun seseorang yang mempunyai kekebalan tubuh yang rendah akan dapat beresiko terkena virus corona ini. berpengaruh.Pada saat musim penghujsn sangat berdampak besar pada covid-19.Covid-19 pada musim gugur dan juga penghujan kasus covid-19 juga semakin banyak..Selain itu,contoh:Si Kevin sedang berlibur di Kota yang sedang kasus virus tertinggi di dunia .Maka Kevin bisa saja pulang ke negara asalnya membawa virus corona.Dan sangat membahayakan orang-orang dirumah.
Corona virus dapat menyebar dengan cara seperti berikut:

1. mudah mengusap muka menggunakan tangan,sedangkan tangan dalam posisi tidak bersih.

2. Tidak pernah cuci tangan setelah bepergian

3. Tidak pernah memakai masker pada saat bepergian

4. Tidak menjaga jarak

5. Dekat-dekat dengan orang yang sedang sakit

6. Terkena air liur sama orang yang terinfeksi virus corona

Covid-19 ada muncul gejala biasanya kurang lebih 2 minggu.Covid-19 bisa berasal dari hewan.Kasus yang beredar awal-awal covid-19 berasal dari hewan melalui air liur.Tidak hanya hewan saja tetapi juga manusia.

Covid-19 dengan sangat mudah bisa mengakibatkan gejala pada orang yang terkena virus covid-19.Biasanya ada bebrapa golongan-golongan gejala orang yang terkena covid-19 ini,yaitu:
1. Ringan
2. Sedang
3. Berat

Sebagai contoh gejala yang ringan yaitu biasanya seperti sakit biasa.Misalnya:

1. Terjadi panas tinggi

2. Badan merasa tidak enak

3. Tenggorokan yang tiba-tiba sakit

4. Terjadi pusing

5. Pilek atau hidung keluar ingus

Beberapa covid-19 dapat menyebabkan gejala yang sangat membahayakan.Covid-19 bisa berubah menjadi penyakit yang serius dan menimbulkan gejala yang sangat berat dan pasti membahayakan tubuh kita.Selain itu,juga bisa berakibat fatal.

Biasanya gejala yang berat seperti berikut:

1. Panas yang sangat tinggi dan harus segera dibawa ke dokter

2. Ada lender pada saat batuk-batuk

3. Terjadi susah napas

4. Terjadi batuk disertai susah bernapas

Covid-19 dapat mudah menjangkit dengan orang yang sudah mempunyai penyakit serius seperti sakit jantung, sakit saluran pernapasan, sakit paru-paru,dll. Apalagi orang yang sudah 
tua dengan mudahnya terkena virus corona.Covid-19 menyerang orang dengan daya tahan tu uh rendah seperti bayi dan juga lansia.Yang bisa mendiagnosis apakah terkena virus corona atau tidak hanya dokter yang bisa.Nantinya dokter akan meneliti lebih lanjut dengan gejala-gejala yang dirasakan pasien.Selain itu,aka nada wawancara antara pasien dengan dokter seputar covid-19 atau gejala-gejala yang dirasakan oleh pasien dan pastinya setelah itu akan ada pemeriksaan lebih lanjut.

Covid-19 dapat menyebabkan penyakit SARS yang sangat berbahaya.SARS sangat membahayakan bagi tubuh kita.Sama halnya dengan virus corona juga dapat menyebabkan penyakit serius seperti komplikasi.Bahkan dengan mudah merenggut korban jiwa.Semua kelompok coronavirus sangat membahayakan pada tubuh kita.Oleh karena itu,kita harus pintar-pintar merawat tubuh kita agar tidak terkena kelompok penyakit corona.

Biasanya orang yang terkena virus corona nantinya akan sembuh sendiri.Tidak ada perawatan-perawatan yang sangat susah.Tapi,tidak akan bisa pulih sendiri jika kita tidak ada usaha-usaha agar cepat sembuh dari virus corona misalnya :

1. Semisal kita demam kita harus segera ke dokter atau membeli obat yang ada di apotek

2. Jika terjadi batuk diusahakan mandi menggunakan air panas

3. Jangan lupa beristirahat yang cukup

4. Harus mengonsumsi vitamin-vitamin agar daya tahan tubuh kita tidak melemah

5. Jika gejala virus corona semakin serius langsung dibawa ke layanan kesehatan terdekat

Orang yang terkena covid-19 biasanya dokter nanti akan memberikan surat rujukan ke rumah sakit yang sudah disediakan untuk pasien virus corona.Jika tidak dirujuk ke rumah sakit biasanya dokter akan menyarankan untuk isolasi mandiri dirumah atau di tempat yang sudah disediakan.Isolasi mandiri biasanya dilakukan selama 2 minggu atau 14 hari.Pada saat isolasi mandiri nantinya akan dilakukan terapi-terapi.Selain itu juga dikasi antibiotik.

Dari dulu sampai sekarang vaksin untuk mencegah virus corona belum ditemukan .Vaksin tersebut sangatlah tidak mudah menemukannya.Para ahli-ahli dalam bidang kesehatan sedang berusaha membuat vaksin tersebut.Prosedur pembuatan vaksin sangatlah tidak mudah harus melalui proses panjang tentunya.Setelah ditemukan nanti akan diuji dengan bahan percobaan.Tetapi, ada beberapa cara untuk mengurangi terjadinya virus corona .Cara-cara yang dilakukan adalah sebagai berikut:

1. Jangan lupa mencuci tangan menggunakan sabun\&cuci tangan harus sampai bersih

2. Jangan sering-sering mengusap muka pada saat tangan keadaan kotor

3. Jangan dekat-dekat pada orang yang sakit

4. Jangan sampai ada kontak langsung pada orang yang sedang sakit

5. Jangan dekat-dekat apalagi menyentuh hewan yang berliur

6. Sering-sering mensterilkan barang-barang yang ada disekitar kita

7. Pada saat bersin atau batuk jangan menutup menggunakan telapak tangan

8. Apabila sakit sebaiknya berdiam diri dirumah tidak bepergian terlebih dahulu

9. Jika keluar jangan lupa memakek masker

10. Apabila sakit segera ke dokter

Jika anda terkena terkena covid-19 jangan sampai panik yang berlebihan.Segeralah ke dokter agar diberikan pelayanan yang tepat dan cepat.Jika pasien sudah ada tanda-tanda gejala virus ini biasanya dokter akan menyarakan untuk isolasi mandiri selama 14 hari.Selama 14 hari tidak cuman berdiam diri saja di kamar,namun juga meminum vitamin atau suplemen selain vitamin,juga harus memakan makanan yang bergizi dan sehat contohnya buah-buahan.Jika setelah isolasi mandiri selama 14 hari tidak membaik maka biasanya dokter akan melakukan swab test yang hasilnya akurat.Setelah hasilnya muncul positif maka anda akan dibawa ke rumah sakit agar mendapatkan pelayanan yang intensif. 
Pada masa pandemi ini kita harus wajib menjaga jarak minimal 1 meter.Wajib memakai masker jika bepergian.Masker tidak menjamin kita terbebas dari covid-19.Tetapi,masker bisa mengurangi infeksi covid-19.Terbukti grafik yang menunjukkan jika masyarakat menggunakan masker atau tidak hasilnya selisih jauh.Dari grafik tersebut betapa pentingnya mengguankan masker pada masa pandemic covid-19.Bukan hanya pada saat covid-19 aja tetapi sebelum ada virus ini kita wajib juga menggunakan masker pada saat berkendara agar tidak terkena debu.Oleh karena itu,mulai sekarang harus hidup sehat agar tidak terkena corona.

Selain itu jangan lupa olahraga dengan rutin agar tubuh tetap sehat dan terhindar dari virus corona.Pada saat berolahraga jangan lupa tetap mematuhi protokol kesehatan menggunakan masker.Berolahragalah yang ringan seperti jogging.

\section{B. Dampak Virus Corona Bagi HAM di Seluruh Dunia}

Virus corona sangat berdampak pada hak asasi manusia tidak hanya di Indonesia saja tetapi di seluruh dunuia.Dampak tersebut sebagai berikut:

\section{- Dalam bidang kesehatan}

Tenaga kerja kesehatan khususnya di negara Indonesia sangat kekuranagan alat pelindung diri.Banyak yang berkarya menggunakan jas hujan,memungut plastic sampah agar dijadikan APD,serta bahan lainnya.Kejadian diatas sangat mengancam hak asasi manusia.Seharusnya tenaga kerja mendapatkan alat perlindungan diri yang kualitasnya bagus agar pada saat bertugas bisa optimal memberikan pelayanan pada pasien.Negara harus berusaha memperbaiki semua fasilitas yang ada khususnya pada kesehatan.Pada masa pandemi layanan kesehatan membutuhkan perhatian yang serius.Agar kesehatan para tenaga medis juga terjamin.Yang mudah terkena covid-19 adalah lansia,bayi,anak-anak.ibu yang sedang mengandung.Semua orang wajib mendapatkan perlindungan.
- Dalam segi Informasi

Dalam segi informasi setiap orang berhak menerima informasi dan mencari informasi.Namun,dalam masa pandemi ini dalam mencari informasi sangatlah dibatasi.Banyak yang diprivasi.Contohnya:seorang wartawan ingin mencari berita tentang covid 19 angka kasusnya.Tetapi sangatlah susah mencari informasi tersebut.Karena banyak yang diprivasi.

Dalam mengakses informasi juga dijamin dalam undang-undang.Berita seputar covid-19 sangatlah diprivasi.Padahal,berita tersebut sangatlah berpengaruh pada semua masyarakat.Kita harus memberikan informasi bagaimana cara pencegahan atau memutus tali rantai persebaran virus corona ini.Mensosialisasikan tentang gaya hidup yang sehat pada masa pandemi.Tetap lakukan social distancing.Sekarang Di internet sudah banyak berita-berita seputar covid-19 berupa gejala,cara pencegahan,tentang isolasi mandiri,dll.

Seluruh masyarakat berharap agar berita seputar covid-19 khususnya angka kasus virus corona ini agar tidak ditutup-tutupi.Kenapa harus diprivasi padahal berita tersebut sangat penting bagi kita.Agar kita tidak asal mengambil langkah yang salah apabila kita tekena covid-19 ini.Tidak ada informasi yang tidak berguna ,semua informasi sangatlah berguna bagi seluruh masyarakat.

\section{- Dalam Segi Privasi}

Privasi sangat penting bagi kita.Misalnya:Keluarga kita ada yang terkena covid-19 setelah itu masuk berita.Dalam berita tersebut dipaparkan alamat rumah tinggal kita.Itu efeknya sangat besar bagi kita khususnya dalam lingkungan di sekitar kita .Pasti orang-orang disekitar kita jadi tidak mau dekat-dekat dengan kita.Selain itu,juga pasti menjadi perbincangan orang-orang di sekitar kita.

Ada undang-undang yang mengatur atas keterbukaan informasi,contohnya pasien yang positif covid-19,psikis,dll yang menyangkut pribadi kita sendiri.jika kita mengijinkan untuk diliput ke dalam berita juga boleh.Tetapi jika tidak ijin berarti termasuk 
pelanggaran yang bisa dihukum.Informasi sangatlah penting bagi kita.Tetapi juga harus memperhatikan privasi perseorangan.Karena jika kita melanggar akan masuk ke ranah hukum.

\section{- Dalam Segi Pekerjaan}

Dalam masa pandemi ini banyak karyawan-karyawan yang diPhk.Bukan hanya di phk tetapi juga biasanya dipotong upah gajinya,tidak ada cuti.UMKM di Indonesia juga melemah,dalam masa pandemi ini banyak orang yang perekonomiannya rendah hal itu juga bergantung pada UMKM di Indonesia.Namun pada beberapa saat kemarin UMKM di Indonesia diberikan bantuan oleh pemerintah.UMKM yang sudah mempunyai ijin usaha.Bukan hanya UMKM saja tetapi karyawan swasta pabrik juga mendapatkan BLT(bantuan langsung tunai) yang sangat bermanfaat bagi kita semua.

Banyak karyawan-karyawan yang tidak masuk pada masa pandemi,biasanya dalam prerusahaan apalagi pada masa pandemi akan memotong cuti karyawan tersebut.Misalnya:Si Kevin bekerja di perusahaan.Kevin pada hari selasa tidak masuk dikarenakan sakit tetapi dia tidak ijin .Maka,atasan perusahaan tersebut memotong atau mengurangi cuti tersebut.Yang awalnya kevin punya 5 cuti menjadi 4 cuti.Kejadian diatas yaitub salah satu cara untuk mengendalikan covid-19.

Banyak karyawan-karyawan yang kekurangan pemasukan karena gajinya dipotong.Bukan hanya karyawan swasta saja tetapi juga UMKM di Indonesia soalnya penjual-penjual di pasaran juga sepi pembeli.Tidak seperti dulu ramai pembeli.Sedangkan penjual-penjual juga butuh uang untuk kehidupan sehari-harinya.Banyak yang pengangguran selama masa pandemi ini.Sebelumnya sudah banyak pengangguran ditambah kondisi seperti ini jadi semakin banyak lagi angka penganggurannya.

Yang paling penting adalah caranya agar covid-19 ini cepat berlalu dan bagaimana caranya dalam mengatasi virus corona ini.Sekali lagi tidak boleh ada pelanggaran dalam hak asasi manusia.Harus bersama-sama bergotong royong agar cepat selesai masa pandemi ini.

Pada bidang penyesoran juga sangatlah terdampak pada masa pandemi ini,dibawah ini adalah penjelasan dari aktivis-aktivis yang terganggu:

- Para Aktivis yang Merasa Sangat Dirugikan atau Terganggu

Banyak orang-yang yang meliput kejadian virus corona di internet maupun lainnya.Biasanya orang -orang yang meliput tersebut nantinya akan diancam oleh orang yang bersangkutan.Ada satu contoh kasus di Tiongkok dia sedang meliput pasien positif virus corona yang pada akhirnya pasien tersebut meninggal dunia.Beliau yang meliput kejadian tersebut akan terkena intimidasi dari pihak-pihak yang bersangkutan.Ada juga mata-mata kejadian tersebut terus dilaporkan kepada pihak berwajib untuk dikenai hukuman.

Semua informasi harus akurat dan benar adanya bukan mengada-ngada.Seperti angka virus corona haruslah sesuai dengan datanya,bukan dilebih-lebihkan atau dikurang-kurangkan apalagi ditutup-tutupi.Semua media juga harus mempunyai tujuan yang jelas untuk siapa berita tersebut apakah bermanfaat untuk seluruh masyarakat.Banyak media-media yang membuat berita tidak jelas dan tidak ada tujuan tentunya.

\section{- Banyak Berita yang di Sensor}

Pada saat virus ini menyebar ke negara negara yang di deket Tiongkok, Tiongkok juga membungkam berita-berita yang ada di negara sebelah juga.Dalam hal inu pemerintah harus meneliti berita-berita yang beredar apakah benar atau tidak. Banyak yang beredar berita palsu tentanf virus corona.Pemerintanh harus memberikan berita - berita yang bermutu seperti halnya cara mencuci tangan yang benar,melakukan 3M atau mematuhi protokol kesehatan.Tiongkok sudah agak mereda virus corona,negara lain juga ingin meniru tindakan-tindakan yang dilakukan Tiongkok agar cepat berkurang virus ini.. Cara menangani virus ini tidaklah mudah. Setidaknya virus ini bisa cepat berkurang 
menggunakan vaksin. Namun, sampai saat ini vaksin untuk virus tersebut belum juga ditemukan.

- Orang-orang Tiongkok mengalami Diskriminasi

Dengan adanya virus corona ini yang berasal dari Tiongkok.Orang-orang di Tiongkok banyak yang yang mengalami diskriminasi dari orang-orang di negara lainnya.Seperti anti orang china dan lain lain,Negara lain sekarang juga menjadi enggan berkunjung ke negara Tiongkok karena awal mula virus corona ini berasal dari negara tersebut.

Sebagai contoh ada orang Tiongkok berkunjung negara tetangga anggap saja berkunjung ke negara Malaysia,mereka orang-orang Tiongkok tidak diperlakukan secara normal.Orang-orang Tiongkok yang masih berada di hotel negara tetangga juga disuruh meninggalkan hotekl tersebut.Tidak menerima tamu-tamu dari Tiongkok atau china.

Upaya yang dilakukan pemerintah adalah dengan mengajak seluruh masyarakat di Dunia ini agar mempunyai rasa solidaritas yang tingi .Jangan melakukan diskriminasi terhadap orang-orang Tiongkok. Selain itu,kita juga harus bersama-sama melawan virus ini pastinya.

- Dalam Mengontrol Perbatasan dan dalam Karantina Harus Seimbang

Banyak negara-negara yang menutup akses untuk orang-orang Tiongkok.Bukan hanya itu,negara-negara lain juga menggunakan cara karantina yang super ketat.Negara-negara yang posisinya perbatasan pun juga banyak menutup area perbatasan tersebut tidak boleh ada yang masuk pada area perbatasan tersebut.Tindakan tersebut untuk mengurangi bertambahnya kasus covid-19 ini.Tindakan tersebut sangatlah bagus namun juga ada sisi negatifnya.Orang-orang yang asli daerah tersebut terdampar di negara tetangga.

Negara Indonesia juga melakukan karantina untuk pasien positif virus corona.Dalam karantina tersebut ada yang dibatasi seperti kebebasan seseorang itu akan
dibatasi.Namun,hal itu sangat bagus dilakukan agar cepet sembuh pasien covid-19.Tujuan karantina juga sah untuk kebaikan kita semua.Yang paling terpenting tidak melanggar hukum yang ada.

Semua orang selama karantina wajib dijaga atau dilindungi bukan hanya itu tetapi juga wajib dihormati tidak boleh membeda-bedakan pada saat karantina berlangsung.Saling menghargai satu sama lain.Diberi makanan yang sehat dan kebutuhan-kebutuhan lainnya.Mendapatkan akses kesehatan yang sama tanpa membeda-bedakan.

Misalnya ada seorang penjabat yang positif virus corona dan harus menjalankan karantina maksimal 14 hari.Pejabat tersebut dalam masa karantina diberikan pelayanan spesial beda dari yang lainya.Sedangkan masyarakat biasa yang terkena covid-19 diberikan pelayanan yang sangat buruk.Kejadian diatas menyalahi aturan yang ada,kita sebagai sama-sama warga negara harus menjunjung tinggi rasa saling menghormati dan menghargai tidak membeda-bedakan.

Banyak negara-negara yang melakukan pelanggaran-pelanggaran yeng mengatas namakan covid-19 khususnya pelanggaran pada hak asasi manusia sebagai contoh kasus diatas merupakan pelanggaran hukum hak asasi manusia yang berkedok covid-19.Tindakan diatas tidak patut di contoh.Setiap negara mempunyai hak-hak untuk seluruh masyarakatnya.SSeperti contoh hak melindungi warga masyarakat.Dalam segi kesehatan juga sangat penting dan wajib dilindungi.Adanya virus ini mengancam pada kesehatan seluruh masyarakat.Jika kita tidak hati-hati maka dapat dengan mudah terkena virus corona.Covid-19 sudah banyak memakan korban jiwa,angka kasusnya yang sangat tinggi.Terlebih angka kasus di Indonesia bukannya menurun malah semakin tinggi kasusnya.

Pelanggaran-pelanggaran tersebut biasanya merujuk pada kaum golongan bawah yang dengan mudah dilecehkan oleh orang yang mempunyai pangkat tinggi.Sangat memprihatinkan dengan situasi seperti ini ditambah kasus pelanggaran-pelanggaran oleh 
oknum yang tidak bertanggung jawab.Para pejabat tinggi malah memanfaatkan kedaan yang ada.Kaum golongan bawah perekenomiannya sangat lah rendah untuk makan saja susah.

Pemerintah sudah mengerahkan untuk menangkap oknum-oknum yang tidak bertanggung jawab agar dipenjara.Keadaan pandemic seperti ini ditambah ada berita-berita yang beredar palsu tidak benar adanya.Agar memberikan efek jera terhadap orang - orang yang sudah memanfaatkan kondisi seperti ini.Kondisi seperti ini seharusnya menampilkan berita-berita yang positif dan real atau benar adanya tidak asal membuat berita yang palsu .

Dengan adanya berita palsu yang beredar masyarakat jadi mudah terpecaya dengan berita-berita yang beredar seperti berita angka kasus covid-19 dilebih-lebihkan.Covid-19 tidak semenyeramkan yang ada di benak kita namun kita harus extra waspada pada covid-19

Untuk itu kita harus lebih berhati-hati dan sering-seringlah membaca berita dari media yang resmi dan sah.Dan memikirkan bagaimana caranya meminimalisir berita-berita yang palsu.Agar masyarakat tidak percaya dengan berita-berita yang beredar. Kita harus menanamkan kepercayaan sejak dini tentang segala hal.

Efek yang ditimbulkan dari virus ini sangatlah banyak dan dalam segi hal apapun contohnya dalam segi ekonomi,budaya,dll

\section{Dampak Virus Corona Bagi Kehidupan Sosial}

Ada beberapa dampak dari covid-19 terhadap kehidupan social terlebih pada kaum hawa di Asia Tenggara,berikut penjelasannya:

- $\quad$ Sekolah - Sekolah di Tutup

Pada masa pandemic ini sekolah pastinya libur karena untuk mengurangi resiko terjadinya virus ini.Anak-anak banyak yang bosan dirumah terus oleh karena itu banyak orang tua yang memprotes pemerintah agar segera masuk sekolahnya.Orang tua sangat pusing menghadapi anak-anaknya dirumah tugas yang sangat numpuk belum orang tuanya sedang bekerja.Belum juga kendala susah sinyal,kuota internet yang sangat boros.Akan tetapi,pemerintah mendengar keluhan tersebut inisiatif memberikan bantuan kuota gratis dari SD sampai SMA bahkan sampai perguruan tinggi.

Oleh karena itu,banyak ibu yang rela membunuh anaknya karena orang tua terkena stress.Ada orang tua juga yang setuju pembelaajaran dilakukan secara daring terus ada juga yang tidak setuju jika pembelajaran terus-terusan dilakukan dirumah.

Pemerintah belum berani jika melakukan sekolah secara offline dalam kedaan seperti ini.Untuk sementara waktu sekolah harus dilakukan secara daring terlebih dahulu jika keadaan sudah memungkinkan untuk belajar secara langsung maka akan segera dilaksanakan secara offline.

Banyak ibu-ibu yang tidak berangkat kerja demi anaknya.Karena,dalam daring ini banyak tugas dan tugasnya harus dikerjain secepat mungkin untuk dikumpulkan.Banyak ibu-ibu yang mengeluh dengan sekolah ditutup namun apa dayanya pemerintah tidak bisa membuka sekolah secara offline tatap muka.Ibu-ibu memprotes dengan penutupan sekolah akan menambah beban para orang tua.Benar juga jika sekolah ditutup akan menambah beban semua orang.Sebagai contoh:Adikku masih SD kelas 3,mempunyai orang tua yang bekerja semua dari pagi hingga sore.Sedangkan tugas adikku sangat menumpuk banyak dan harus dikumpulkan hari itu juga.Padahal,orang tua adikku sudah sangat lelah ditambah tugas-tugas sekolah yang menumpuk.Sedangkan si anak tidak bisa menangkap pelajaran.Jadi selama daring ini orang tua lah yang seperti belajar seharusnya anaklah yang rajin belajar bukan pergi bermain terus.

- Banyak Terjadinya Kekerasan Rumah Tangga

Dalam masa pandemic banyak orang orang yang perekonomiannya rendah.Hal itu dapat memicu pertengkaran dalam rumah tangga.Karena banyak yang dipecat atau diPHK oleh perusahaannya.Negara di Indonesia Mayoritas pekerjaannya sebagai karyawan swasta.Tidak hanya karyawan swasta saja tetapi juga menjadi 
pedagang.Sama halnya dengan karyawan swasta pedagang juga sepi pembeli.Penghasilannya sangat sedikit dan tidak konsisten.

Sedangkan para orang tua kebutuhannya sangat banyak untuk anak-anaknyaDitambah lagi dengan pengangguran akan memicu kekerasan rumah tangga.Banyak kejadian cerai akhir-akhir ini oleh karena itu sebagai orang tua harus lebih bersabar dengan kondisi yang seperti ini.Harus extra bersabar agar tidak fatal.Angka kasus perceraian sebelum pandemic dan sesudah pandemic sangatlah berbeda jauh.Sebelum pandemi angka perceraian dan kekerasan rumah tangga sangatlah rendah.Namun,setelah ada pandemi angka perceraian sangatlah tinggi.Banyak yang melapor dengan kasus kekerasan rumah tangga terlebih di Indonesia.

- Tenaga Kerja Kesehatan Banyak Kaum Perempuan

Tenaga kerja layanan kesehatan banyak yang kaum perempuan.Seperti perawat,suster,dll justru malah banyak kaum perempuan.Ada kasus perawat yang sedang hamil,perawat tersebut sampai keguguran karena kelelahan dalam bekerja.Tetapi perawat tersebut langsung kembali bekerja.Padahal,jam kerja perawat apalagi pada saat wabah virus ini sangatlah tidak sedikit,waktunya sangat panjang bahkan lebih dari 9 jam.Sangatlah miris tenaga kerja kesehatan sangatlah kekurangan.Beda dengan negara lainnya yang melimpah tenaga kerja layanan kesehatannya.Di Tiongkok kasus covid-19 sudah sangat berkurang beda dengan negara Indonesia yang semakin terus bertambah.Bahkan di Tiongkok para perawat dikasih penghormatan dan mendapat dukungan penuh dari seluruh masyarakat.Beda dengan di Indonesia para perawat atau para tenaga medis justru malah dihindari tidak dihargai dan tidak dihormati,padahal merekalah yang menjadi garis terdepan pada saat wabah virus ini.Tidak mendapat dukungan juga oleh masyarakat.Gaji yang tidak terlalu banyak,tetapi para tenaga medis tetap bekerja sepenuh hati agar virus ini cepat selesai dan berlalu.
- Banyak Pekerja yang Migran

Banyak warga negara Indonesia yang bekerja menjadi pembantu di negara-negara tetangga.Biasanya banyak

yang bekerja di negara Tiongkok.Pada masa covid-19 ini banyak para tenaga kerja dari Indonesia yang dipecat oleh majikannya.Karena situasi perekonomian yang sangat sulit,pendapatan yang sangat rendah.Gaji yang tidak pasti kadang sedikit kadang juga banyak.

Para tenaga kerja Indonesia sangat susah menemukan masker.Di Tiongkok pada saat awal-awal virus corona ini menyebar sangatlah susah menemukan produk masker.Ada masker tetapi hanya sedikit itupun harganya juga sangat mahal.

Ada juga pekerja tenaga Indonesia yang mempunyai masker yang diberikan oleh majikannya.Banyak tenaga kerja Indonesia yang pulang ke negara asalnya karena mereka takut terpapar virus corona ini.Apalagi virus ini bermula di Tiongkok.Banyak juga tenaga kerja Indonesia yang terjebak di Tiongkok.Media Indonesia cuman bisa meliput berita melewati Video Call karena jarak yang jauh yang tidak memungkinkan bertemu.Namun akhirnya tenaga kerja Indonesia bisa pulang juga ke negara asalnya namun dengan melakukan banyak prosedur-pprosedur yang dilakukan contohnya setiba di Indonesia harus menjalani masa karantina dan test covid-19.

\section{Dampak Virus Corona bagi Lingkungan Alam ,Ekonomi,dan Keluarga}

- Lingkungan Alam

Physical distancing yang merupakan aturan baru agar masyarakat berdiam diri bahkan menghabiskan waktunga di rumah ternyata sangat berpengaruh terhadap kondisi alam.Kegiatan ekonomi dan transporytasi juga turut berpengaruh pada lingkungan.Ini membuat emisi karbon turun secara tiba-tiba.Tingkat polusi di New York telah berkurang hamper $50 \%$ di China emisi turun $25 \%$ karena masyarakat diperintahkan untuk tinggal di rumah.

Di negara Tiongkok kualitas uadaranya telah naik sebesar 11,4\%.Di Eropa dan di 
Italia emisi nitrogen dioksida (N02) memudar karena turunnya tingkat transportasi.

- $\quad$ Lingkungan Ekonomi

Akibat pandemi virus corona IMF menyatakan jika dunia tengah mengalami krisis.Karena konsumsi rumah tangga terus melambat padahal menjadi pendorong utama perekonomian.

Virus corona juga turut menyerang pasar saham.Investor takut jika mereka tidak sanggup menghentikan penurunan karena virus dapat menghancurkan segala perekonomian.Bahkan di Indonesia Indeks Harga Saham Gabungan (IHSG) turun hingga 24 persen.Dan kurs rupiah melemah hingga 5,41 persen dalam kurun waktu 6 bulan terakhir karena akibat dari keluarnya dana asing.

- Lingkungan Keluarga

Masa karantina mandiri yang sudah dijalani selama 5 bulan memberikan efek positif yang secara tidak langsung memberikan kesan dan banyak waktu kepada keluarga untuk lebih mengenal anggota keluarganya.Orang tua bisa lebih tau sifatnya anaknya.Dan tanpa kita sadari,pandemic covid-19 juga memberikan kesempatan orang tua untuk berkumpul dan lebuh mengenal dengan anak-anaknya.

Bahkan anggota keluarga juga dapat berkumpul dan menghabiskan waktu di rumah bersama keluarga dan saling menyesuaikan diri dan mereka juga dapat menyelesaikan masalah bersama-sama walaupun di masa pandemic.Namun dampak negative karantina mandiri selama pandemic juga menghantui yakni sering terjadi masalah dengan keluarganya karena adanya perbedaan pendapat.Yang seharusnya bisa disikapi dengan baik sehingga selalu damai.

Pola hidup yang seperti itu bukan pola hidup new normal.Karena manusia diharapkan selalu bisa menyesuaikan diri.Namun ada beberapa orang yang mungkin bisa cepat beradaptasi dan juga lama untuk beradaptasi dengan baik.

\section{E. Dampak Negatif Virus Corona bagi Seluruh Kehidupan}

- Meningkatkan Penyalahgunaan Narkoba dan Alkohol

Masyarakat merasa bosan karena keadaan yang mengharuskan mereka berdiam diri dan menghabiskan waktunya dirumah.Kebosanan ini yang menimbulkan kegiatan buruk,yang biasanya bebas beraktivitas diluar rumah harus melakukan kegiatannya dirumah dan itupun harus bahkan dalam waktu yang cukup lama.Sungguh membuat kebosanan dan kejenuhan yang luar biasa.Bagi orang-orang tertentu akan membuat mereka berfikir untuk melakukan hal-hal yang negative khususnya bagi mereka yang memang tidak bisa berdiam diri dirumah.

Keadaan seperti ini membuat sebagian masyarakat merasa sress bahkan frustasi uang akibatnya mengalihkan pikirannya pada hal-hal yang kurang baik dan mendukung aktivitas yang nantinya juga akan merugikan diri sendiri.Sebagian masyarakat pun mengalihkan kejenuhannya ke narkoba untuk menghabiskan waktu dan menghibur diri.

- Membuat Kepanikan Belanja dan Menurunnya Stok Barang

Virus corona dari hari ke hari membuat korban semakin meningkat.Kabar-kabar yang kurang baik mengenai keganasan virus simpang siur ada yang benar ada yang salah,sehingga membuat masyarakat bingung. Yang akhirnya membuat kepanikan yang begitu hebatnya di kalangan masyarakat apalagi saat pemerintah membuat aturan baru yakni agar masyarakat tetapi di dalam rumah,termasuk pelajar bahkan pekerja yang harus melakukan kegiatannya dirumah untuk memutus rantai penyebaran virus.

Namun kepanikan masyarakat yang ingin terhindar dari pandemic corona ini ditambah peraturan agar ttetap dirumah yang malah mengakibatkan kepanikan.Yang akhirnya mengakibatkan kelangkaan barang seperti:masker,handsanitizer,alcohol,dan alat pelindung diri.Hal ini membuat harga barang-barang melonjak tinggi di pasaran bisa naik 2 kali lipat bahkan lebih. 
- Permintaan Meningkat

Terjadinya peningkatan barang-barang pelindung diri membuat kelangkaan bahkan untuk memenuhi kebutuhan medis sekalipun seperti masker,APD yang menunjukkan jika pemerintah belum siap menghadapi wabah inii.Akhirnya para tenaga medis tidak menggunakan perlengkapan atau senjata secara lengkap ketika menghadapi dan mengurus pasien yang terinfeksi.

Padahal para tenaga medis menjadi garda kedepan yang harus dijaga kesehatannya pula.Akibatnya,banyak tenaga medis yang gugur dalam melawan pandemic ini.Karena,kurangnya persiapan pemerintah juga.

- Ancaman Fisik dan Mental ke Tenaga Medis

Garda terdepan dalam peperangan melawan virus corona yaitu para medis baik dokter maupun perawat.Banyak jutaan orang di dunia tetapi pekerjaan ini tidak bisa sembarangan dikerjakan oleh orang-orang lain.Pasien-pasien yang terinfeksi virus corona dapat dibanu dan diatasi oleh mereka yang memiliki keahlian pengetahuan dan keterampilan yang tinggi.Para tenaga medis harus bekerja extra keras karena jumlah pasien yang bertambah secara drastis setiap harinya.Keadaan ini juga bisa membuat mereka kelelahan baik secara mental dan fisik.Tidak hanya itu mereka juga bisa stress dan depresi.Mereka juga lebih terancam akan terinfeksinya virus.

Ketersediaan peralatan medis seperti APD dan masker untuk melindungi diri yang sangat minim bahkan tidak ada membuat keadaan semakin parah.Padahal merekalah yang lebih mudah terinfeksi virus dan akhirnya benar jika banyak dokter dan perawat ikut terinfeksi bahkan gugur saat bertugas.

Beban dan duka yang harus dirasakan tidak hanya karena kehilangan teman seperjuangannya takut terinfeksi tetapi juga karena harus terpisah dari keluarganya.Mereka rela dan bahkan ada yang tidak berani pulang dan tetap memilih tinggal dirumah sakit karena mereka tidak ingin keluarganay terinfeksi,lebih baik gtidak bertemu dulu daripada resiko yang lebih parah.

- Berkurangnya Interaksi dan Sosialisasi

Salah satu penularan virus corona bisa terjadi jika seorang bersin atau batuk mengeluarkan cairan lalu terkena ke orang lain.Virus yang dari cairan bersin itu jika menempel pada media seperti meja,kursi,baju,dan lainnya bisa bertahan hingga hitungan jam bahkan hitungan hari.Maka adanya pandemic ini membuat sedikit berbeda cara berinteraksi social dalam kehidupan masyarakat.Sekarang masyarakat menerapkan agar tidak berjabat tangan,cipika-cipiki atau berpelukan bahkan saat bersama pun tidak boleh berdekatan karena menghindari penularan virus,yang disebut dengan cara tidak berkontak langsung dengan orang lain.Kondisi ini sungguh berbedaa dengan kondisi biasanya ini,dapat merubah keakraban.Padahal sebelum adanya virus masyarakat secara bebas melakukan kontak langsung dengan orang lain.

\section{- Penggunaan Transportasi Menurun}

Adanya transportasi massal dengan tujuan untuk memfasilitasi masyarakat dan mengurangi kemacetan serta polusi.Transportasi massal memang benar-benar bermanfaat bagi masyarakat karena untuk mencapai tempat tujuan lebih cepat tanpa terjebak macet namun,kondisi ini sebelum adanya wabah.Setiap harinya masyarakat memadati angkutan massal seperti bus dan kereta api yang artinya dalam satu armada bus atau gerbong kereta terdapat banyak orang untuk menuju suatu tempat.

Namun adanya wabah masyarakat takut untuk menggunakan transportasi massal.Karena penularan terbesar bisa terjadi akibat tidak diterapkannya social distancing didalam armada.Membuat mereka lebih berhati-hati dan ada yang memilih menggunakan kendaraan pribadi demi keamanan untuk menunjang aktivitasnya.

- Meningkatkan Transaksi Non Tunai

Transaksi non tunai saat ini mengalami perkembangan yang cukup pesat.Ini karena 
perkembangan teknologi yang semakin maju hingga memungkinkan masyarakat untuk melkukan jual beli secara online.

Apalagi adanya wabah ini membuat masyarakat lebih mempercayakan transaksi secara online karena untuk mengurangi penyebaran virus.Pembayaran secara tunai saat ini sudah dibatasi bahkan tidak diterima lagi oleh beberapa took yang artinya pembayaran dilakukan secara non tunai.

Transaksi non tunai ini meningkat karena masyarakat takut terhadap ketidakamanan uang secara nyata.Karena didalam uang kertas maupun logam beresiko membawa virus dan menjadi media penularan.Itu dapat dipercaya karena uang secara cepat berpindah dengan cepat dari satu tangan ke tangan lainnya.Sehingga mudah dihinggapi atau membawa berbagai kuman penyakit dan virus seperti virus corona.

\section{F. Dampak Positif Virus Corona Bagi Seluruh Kehidupan}

- Meningkatkan Kesadaran Masyarakat akan Pola Hidup Sehat dan Bersih

Saat ini sering-sering mencuci tangan menjadi salah satu cara yang sangat dianjurkan untuk menghindari penularan virus corona.Cuci tangan yang benar dengan memperhatikan langlah-langkahnya. Serta menggunakan sabun dan air mengalir.Padahal sebelum ada pandemic ini banyak masyarakat yang lalai terhadap kebersihan tangan.

Sekarang semua masyarakat di dunia benar benar menjaga kebersihan diri sendiri demi mencegah penularan virus seperti rajin mencuci tangan yang menjadi penyalur pertama peneyebaran virus ini.Masyarakat pun mulai menerapkan pola hidup sehat dengan cara makan-makanan yang bergizi mengkonsumsi vitamin dan suplemen untuk menjaga kekebalan tubuh.Ketakutan dan kewaspadaan masyarakat tidak hanya pada kebersihan dan kesehatan tubuh saja namun juga lingkungan tempat tinggal.

Adanya pandemic virus ini masyarakat juga berusaha memusnahkan dengan cara menyemprotkan disinfektan secara ritin di lingkungan tempat tinggal untuk membunuh kuman bahkan virus.
- Langit menjadi Sangat Cerah dan Berkurangnya Polusi

masa pandemi ini banyak pabrik-pabrik yang memberhentikan operasionalnya.Banyak mesin-mesin yang tidak beroperasi karena permintaan konsumen sedikit beda dengan sebelum adanya corona ini permintaan sangat banyak setiap harinya akan mesin-mesin akan beroperasi secara optimal.Namun pada saat wabah ini ada dampak positifnya yaitu langit menjadi sangat cerah karena polusi dari pabrik-pabrik juga berkurang ditambah masyarakat pada dirumah tidak bepergian menggunakan transportasi umum.Udara juga menjadi segar dan sangat cocok dimanfaatkan untuk berolahraga agar terhindar dari virus corona ini.Selain itu,sungai-sungai menjadi sangat jernih sekali.Apalagi diperdesaan yang masih sangat asri jauh dari kata polusi.

\section{SIMPULAN}

Dari paparan yang sudah disampaikan diatas kita harus extra lebih hati-hati agar terhindar dari virus corona ini.Karena virus ini sangat berbahaya bagi tubuh kita.Banyak dampak-dampak yang negatif dari virus ini.Mulai saat ini kita harus hidup sehat agar terhindar dari virus corona.Jika kita menerapkan hidup sehat maka virus corona tidak mau menempel pada tubuh kita.

Jangan lupa selalu terapkan 3M mencuci tangan,memakai masker,menjaga jarak.Pola hidup sehat sangatlah mudah dengan membiasakan mencuci tangan pakai sabun,menggunakan

handsanitizer,membersihkan benda benda yang ada di sekitar kita .karena benda -benda tersebut bisa jadi menjadi sumber penyakit untuk tubuh kita.Caranya sangat mudah dengan membersihkan benda tersebut menggunakan cairan disinfektan.Biasanya di kampong-kampung akan melakukan pemyemprotan cairan disinfektan ke rumah-rumah agar terhindar dari virus corona yang sangat berbahaya bagi tubuh kita.

Upaya-upaya yang dilakukan oleh pemerintah maupun individu sangatlah bagus.Kita sebagai masyarakat harus mematuhi protocol kesehatan yang ada patuh pada peraturan yang sudah diatur. 
Dengan adanya virus ini banyak orang di seluruh dunia menghabiskan waktunya di rumah seperti bekerja dari rumah,beribadah dari rumah,dal lainnya.Dalam kondisi seperti ini sebaiknya tetap berdiam diri dirumah jangan keluar apabila tidak dalam kedaan yang mendesak dan ada keperluan yang sangat penting.Namun,banyak masyarakay yang tetap nekat bepergian berliburan ke tempat wisata,padahal hal tersebut sangatlah membahayakan bagi tubuh kita maupun membahayakan orang lain.Hal tersebut tidak patut dicontoh.

Banyak pula kekerasan rumah tangga yang terjadi .Hal tersebut sangatlah menyedihkan situasi yang seperti ini ditambah kasus tersebut yang mengakibatkan banuyak perceraian yang terjadi di negara-negara khususnya di negara Indonesia.Sebaiknya jika ada masalah harus diselesaikan dengan cara bik-baik bukan dengan cara kekerasan.

Banyak orang yang tidak percaya dengan kasus covid-19 ini.Padahal benar adanya kasus ini yang sangat berbahaya.Gejala-gejala yang ditimbulkan memanglah seperti sakit biasa tetapi ada satu hal yang mencolok pada gejala virus corona yaitu tidak bisa mencium bau.Misalnya:Aku sedang menggoreng ikan asin,tetapi aku tidak bisa mencium bau tersebut.Padahal bau ikan asin sangatlah kuat.Hal tersebut wajib kita curigai dan harus segera periksa ke layanan kesehatan agar ditindaklanjuti atau dengan cara isolasi mandiri dirumah selama 14 hari.Jika gejala tersebut masih tetap ada maka segeralah ke dokter agar mendapatkan hasilnya apakah positif atau negatif covid-19.

Pemerintah berharap agar virus ini cepat berlalu dan keadaan kembali normal seperti biasanya.Pemerintah juga banyak mengalami kerugian pada sistem keuangannya.Gaji para karyawan swasta dan lainnya banyak yang dipotong oleh karena itu kita semuanya berharap agar cepat selesai virus covid-19.

Pada saat awal-awal kasus corona di Tiongkok masker sangatlah susah ditemukan sekarang dengan mudah masker banyak diperjualbelikan di pasar dengan harga terjangkau tentunya.Masker medis dulu sangatlah jangka banyak orang yang memburu bahkan menimbun barang-barang yang langka pada saat itu,sekarang masker banyak diluaran.

Sama halnya dengan masker dulu pada awal-awal virus ini handsanitizer sangatlah langka di pasaran sudah tidak ada.Biasanya ada satu atau dua handsanitizer itupun harganya sangat mahal melonjak tinggi.Dulu orang-orang berbondong-bondong memburu alat-alat pelindung diri dari covid-19.Dulu yang miskin tambah miskin tertindas,karena yang mampu membeli barang-barang tersebut hanyalah orang kaya.Namun,sekarang masker,handsanitizer sangatlah banyak dijual dipasaran dan harganya sudah kembali normal.

\section{DAFTAR RUJUKAN}

Nuryana,Agus,Nana,M.M,Pd,(Sabtu,23 Mei 2020,20:48

Pandemi Covid 19 terhadap Dunia Pendidikan"

https://kabar-prcangan.com/dampak-pand emi-covid-19-terhadap-dunia-pendidikan/

Nasional,Amnesty,(Jumat,07 Februari 2020,07:56 WIB) "Tujuh Dampak Penanggulangan Virus Corona pada HAM"

https://www.amnesty.id/7-dampak-penan ggulangan-virus-corona-pada-hak-asasi-manu sia/

Nasional,Amnesty,(Kamis,9 April 2020 ,04:20 WIB) "Covid-19 dan Hak Asasi Manusia"

https://www.amnesty.id/covid-19-dan-ha k-asasi-manusia/

\section{Simulasi}

Kredit "Dampak Pandemi Virus Corona terhadap Dunia"

https://www.simulasikredit.com/dampakpandemi-virus-corona-terhadap-dunia/

Kumparan,(Senin,30 Maret 2020,16:48 WIB) "Dampak Virus Corona Bagi Lingkungan Sosial,Ekonomi, hingga Alam”

https://kumparan.com/Berita\%20Hari\%2 0Ini/dampak-virus-corona-bagi-lingkungan-so sial-ekonomi-hingga-alam-lt7qNLhBsbk 
Pranand,Dandi,(Senin,17 Agustus 2020,14:46 WIB) "Dampak Positif dan Negatif Covid-19 bagi Kehidupan Keluarga"

https://www.kompasiana.com/dandiprana nda3313/5t3a35e4d54Idf2d49235282/dampak -positif-dan-negatif-covid-19-bagi-kehidupankeluarga

Dr.Jaya,Selviana,Indah.(Sabtu,2 Mei 2020) "Artikel Kesehatan Mengenal Covid 19 ”

https://vivahealth.co.id/article/detail/1349 /mengenal-covid-19

Dr.Fadli,Rizal.(Rabu,08 Juli 2020) "Virus CoronaPenyebab, Gejala,dan Pencegahan" navirus

https://www.halodoc.com/kesehatan/coro

Amalia,Happy,Amanda,(Selasa,28 April 2020,09:25) "Pandemi Covid 19 dapat Ciptakan Bencana HAM"

https://investor.id/international/pandemi-c ovid19-dapat-diciptakan-bencana-ham

Owe,Lara,(Senin,9 Maret 2020) "Bagaimana Wabah Virus Corona Hantam Kehidupan Perempuan di Asia"

https://www.bbc.com/indonesia/indonesia $-51717312$

Ridwan, Muhammad,(Kamis,6 Februari 2020,17:46 WIB) "Virus Korona Berdampak pada Pemenuhan Hak Asasi Manusia di Dunia”

https://www.jawapos.com/nasional/06/02/ 2020/virus-korona-berdampak-pada-pemenuh an-hak-asasi-manusia-di-dunia/?amp

Wikipedia "Pandemi Covid-19" https://id.m.wikipedia.org/wiki/pandemi_ covid-19

Promkes Kementrian Kesehatan RI dan Perhimpunan Dokter Paru Indonesia ."Informasi Tentang Virus" https://stoppneumonia.id/informasi-tentan g-virus-corona-novel-coronavirus/
Republika Indonesia, (Rabu,15 Juli 2020,01:12 WIB) "Tiga Dampak Besar Pandemi Covid-19 Bagi Ekonom Ri",

https://republika.co.id/berita/qd9t5p383/ti ga-dampak-besar-pandemi-covid19-bagi-ekon omi-ri

Health Wellness "Yang Perlu Anda Ketahui Tentang Coronavirus(covid 19)",

https://www.cigna.co.id/health-wellness/y ang-perlu-anda-ketahui-tentang-coronavirus 